\title{
VARIASI SPASIAL DAN TEMPORAL TERHADAP KOMPOSISI JENIS IKAN YANG BERASOSIASI PADA EKOSISTEM MANGROVE DESA LAMONTOLI KECAMATAN BUNGKU SELATAN
}

\section{Spatial and Temporal Variations of Composition Types of Associated Fish in The Mangrove Ecosystem Village Lamontoli, Sub-District South Bungku}

\author{
Rusham Muhu ${ }^{1 *}$, Muhammad Ramli², Wa Nurgayah² \\ 1,2Jurusan Ilmu Kelautan, Fakultas Perikanan dan Ilmu Kelautan, Universitas Halu Oleo. \\ Jl. H.E.A Mokodompit Kampus Hijau Bumi Tridharma Anduonohu Kendari 93232, Telp/Fax: (0401) 3193782 \\ *Email : rushamuhuik1082@gmail.com
}

\begin{abstract}
Abstrak
Ekosistem mangrove merupakan daerah spawning, nursery ground dan tempat berlindung bagi berbagai jenis ikan. Penelitian ini bertujuan untuk mengetahui komposisi jenis ikan pada ekosistem mangrove berdasarkan fase bulan gelap, $1 / 4$ bulan terang, bulan terang, $1 / 4$ bulan gelap dan untuk mengetahui hubungan kerapatan mangrove terhadap komposisi jenis ikan. Penelitian ini dilaksanakan di perairan Desa Lamontoli selama satu bulan dengan 4 kali pengambilan sampel. Ikan yang ditangkap menggunakan jaring insang dengan mata jaring 1,5 inci. Data dianalisis dengan melihat indeks keanekaragaman, dominansi dan keseragaman. Selama penelitian ditemukan 1.086 ekor ikan yang terdiri dari 15 spesies dan 10 famili. Secara berturut-turut, ditemukan 142 ekor, 152 ekor, 355 ekor dan 86 ekor pada fase bulan gelap, 1/4 bulan terang, bulan terang, dan $1 / 4$ bulan gelap. Pada ekosistem mangrove dengan kerapatan tinggi, nilai keanekaragaman ikan berada pada kategori sedang pada fase bulan gelap dengan nilai $\left(\mathrm{H}^{\prime}=2,512\right)$, keseragaman tinggi pada fase $1 / 4$ bulan gelap $(E=1,148)$ dan dominansi tertinggi pada fase $1 / 4$ bulan terang $(C=0,176)$ dan keanekaragaman terendah pada fase $1 / 4$ bulan gelap dengan nilai $\left(\mathrm{H}^{\prime}=1,919\right)$, keseragaman terendah pada fase $1 / 4$ bulan terang $(\mathrm{E}=0,873)$ dan dominansi terendah pada fase bulan gelap $(\mathrm{C}=0,090)$. Pada ekosistem mangrove dengan tingkat kerapatan sedang, keanekaragaman tertinggi pada fase bulan gelap dengan nilai $\left(H^{\prime}=2,217\right)$, keseragaman tertinggi pada fase $1 / 4$ bulan gelap $(E=1,103)$ dan dominansi tertinggi pada fase $1 / 4$ bulan gelap $(C=0,222)$ dan keanekaragaman terendah pada fase $1 / 4$ bulan gelap dengan nilai $\left(H^{\prime}=1,755\right)$, keseragaman terendah pada fase $1 / 4$ bulan terang $(E=0,941)$ dan dominansi terendah pada fase bulan gelap $(\mathrm{C}=0,137)$. Secara umum keseragaman jenis cukup tinggi dan menunjukan bahwa tidak ada jenis ikan yang mendominasi serta penyebarannya merata. Tingginya kelimpahan ikan sangat dipengaruhi oleh kerapatan mangrove dan perbedaan fase bulan.
\end{abstract}

Kata Kunci : Komposisi Jenis Ikan, Mangrove, Fase Bulan, Perairan Desa Lamontoli.

\begin{abstract}
Mangrove which commonly grow in salty waters are home to a variety of flora and fauna and provide nursery grounds, spawning grounds and shelters for various type of fish. This study aims to determine the composition of fish species in the mangrove ecosystem based on the phases of the dark moon, $1 / 4$ bright moon, bright moon, $1 / 4$ dark moon and to determine the correlation between mangrove density and the composition of fish species. This research was conducted in Lamontoli Seawaters for one month with 4 times the sampling. Fish was caught using gill nets with 1.5 inch of mesh size. Fish compositions were analyzed through diversity, dominance and uniformity index analysis at each moon phase. During the study, 1,086 fishes were found consisting of 15 species and 10 families. A total 142 ind, 152 ind, 355 ind and 86 ind of fishes were found in the dark moon, 1/4 bright moon, bright moon, and 1/4 dark moon phase respectively. In high density mangrove area, the diversity of fish was in medium category in the dark moon phase with a value $\left(\mathrm{H}^{\prime}=2.512\right)$, the highest uniformity in the $1 / 4$ dark moon phase $(E=1.148)$ and the highest dominance in $1 / 4$ bright moon phase $(C=$ $0.176)$ while the lowest diversity occured in e $1 / 4$ dark moon phase with a value $\left(H^{\prime}=1.919\right)$, the lowest uniformity in $1 / 4$ bright moon phase $(\mathrm{E}=0.873)$ and the lowest dominance in the dark moon phase $(\mathrm{C}=0.090)$. In mangrove area with moderate density, the highest diversity occured in dark moon phase with a value $\left(H^{\prime}=2.217\right)$, the highest uniformity in $1 / 4$ dark moon phase $(E=1.103)$ and the highest dominance in $1 / 4$ dark moon phase $(C=0.222)$ while the lowest diversity occured in $1 / 4$ dark moon phase with a value $\left(\mathrm{H}^{\prime}=1.755\right)$, the lowest uniformity in $1 / 4$ bright moon phase $(\mathrm{E}=0.941)$ and the lowest dominance in the dark moon phase $(\mathrm{C}=0.137)$. Species uniformity was generally quite high. There was no dominating fish species with equally distributed. The high abundance of fish was strongly influenced by the density of mangroves and the differences of moon phase.
\end{abstract}

Keywords: Fish Composition, Mangrove, Moon Phase and Lamontoli Seawaters.

\section{Pendahuluan}

Hutan mangrove merupakan komunitas vegetasi pantai tropis yang terdiri atas beberapa spesies yang mampu tumbuh dan berkembang pada daerah pasang-surut pantai berlumpur. Hutan mangrove tumbuh berbatasan dengan darat pada jangkauan air 
pasang tertinggi sehingga ekosistem ini merupakan daerah transisi yang dipengaruhi oleh eksistensi faktor darat dan laut. Kawasan hutan mangrove terjadi interaksi kompleks antara sifat fisika dan biologi laut yang ditandai dengan banyaknya jenis hewan dan jasad renik yang berasosiasi dengan hutan mangrove (Halidah, 2007).

Mangrove berperan sebagai habitat alami berbagai jenis biota akuatik maupun organisme teresterial baik sebagai tempat mencari makan (feeding ground), tempat asuhan (nursery ground) maupun sebagai tempat berkembang biak (spawning ground).

Ikan yang terdapat pada ekosistem mangrove, baik yang menetap atau hanya transit untuk melakukan pemijahan serta memelihara anakannya akan menambah keanekaragaman hayati pada ekosistem tersebut. Lebih lanjut Chong et al. (1990) menyatakan bahwa berbagai jenis ikan yang relatif masih berukuran anakan (juvenil) baik ikan penghuni tetap maupun ikan pengunjung mencari makan di sekitar mangrove, terutama pada waktu air pasang, terjadinya pasang dan surut muka air laut juga sangat di pengaruhi oleh fase bulan.

Periode bulan memperanguhi juga sebaran organisme laut karena perode bulan berhubungan dengan pergerakan muka air laut di wilayah pesisir sehingga nutrien yang ada di perairan akan tersebar hingga di wilayah estuary dan sampai wilayah mangrove sehingga akan berpengaruh pada organisme akuatik seperti ikan untuk mencari makan di wilayah pesisir khususnya daerah mangrove.

Sebaran mangrove di Desa Lamontoli terbagi atas dua wilayah, bagian Timur kondisi mangrove kategori kerapatannya sedang dan di bagian Barat kondisi mangrove kategori padat, kerusakan mangrove terjadi karena di bagian Timur jarak pemukiman sangat dekat dan masyarakat memanfaatkan mangrove juga sebagai kayu bakar dan perabot rumah tangga.

Perairan Lamontoli terletak di pesisir Selatan Kecamatan Bungku Selatan, memiliki ekosistem pesisir yang kompleks terdiri atas ekosistem mangrove, lamun dan terumbu karang, kondisi ekologis tersebut memberikan konsekuensi pada keanekaragaman hayati yang cukup tinggi dengan sifat dan karakteristik tersendiri serta mempunyai potensi ekonomis untuk dikembangkan. Salah satu sumber daya alam yang bernilai ekonomis penting adalah sumber daya perikanan laut, baik itu sumber daya ikan maupun non ikan. Hal ini menempatkan parairan tersebut menjadi sumber pendapatan para nelayan untuk memenuhi kebutuhan harian keluarga dan bahkan menjadi sumber pendapatan masyarakat di Desa tersebut.

Sehubungan dengan pentingnya ekosistem mangrove bagi keberadaan sumber daya ikan perlu dilakukan penelitian dalam rangka menentukan hubungan antara kondisi ekosistem mangrove dan keanekaragaman ikan yang ada di dalamnya, khususnya di daerah pantai Desa Lamontoli yang saat ini sedang mengalami kerusakan. Hasil penelitian ini selanjutnya dapat dijadikan informasi dasar dalam pemanfaatan kawasan mangrove agar pemanfaatannya dapat berkelanjutan.

Penelitian ini bertujuan untuk mengetahui komposisi jenis ikan pada ekosistem mangrove berdasarkan fase bulan gelap, $1 / 4$ bulan terang, bulan terang, $1 / 4$ bulan gelap dan untuk mengetahui hubungan kerapatan mangrove terhadap komposisi jenis ikan.

\section{Bahan dan Metode}

Penelitian ini telah dilaksanakan pada bulan Novenber 2018. Pengambilan sampel mangrove dan analisis kualitas air, serta identifikasi jenis ikan dilakukan di Perairan Desa Lamontoli Kecamatan Bungku Selatan, selama 1 bulan.

Prosedur penelitian meliputi tahap persiapan, penentuan stasiun penelitian, kerapatan mangrove, keanekaragaman jenis mangrove, dan keanekaragaman jenis ikan yang ada pada ekosistem mangrove.

Observasi lapangan untuk mengetahui kondisi lapangan, penentuan titik stasiun, dan penentuan metode penelitian. Penentuan stasiun pada lokasi penelitian dibagi berdasarkan variasi spasial terdiri dari 2 stasiun pengamatan. Stasiun 1 berada di wilayah bagian timur dengan titik koordinat $03^{\circ} 08^{\prime} 20.9^{\prime \prime} \mathrm{S} 122^{\circ} 24^{\prime} 05.2^{\prime \prime} \mathrm{E}$. dibagi menjadi tiga titik sebagai ulangan pengambilan data ikan. Stasiun 2, berada di wilayah bagian barat titik koordinat $03^{\circ} 08^{\prime} 26.4^{\prime \prime} \mathrm{S}$ $122^{\circ} 23^{\prime} 47.9^{\prime \prime} \mathrm{E}$. terdapat tiga titik sebagai ulangan pengambilan data ikan. 


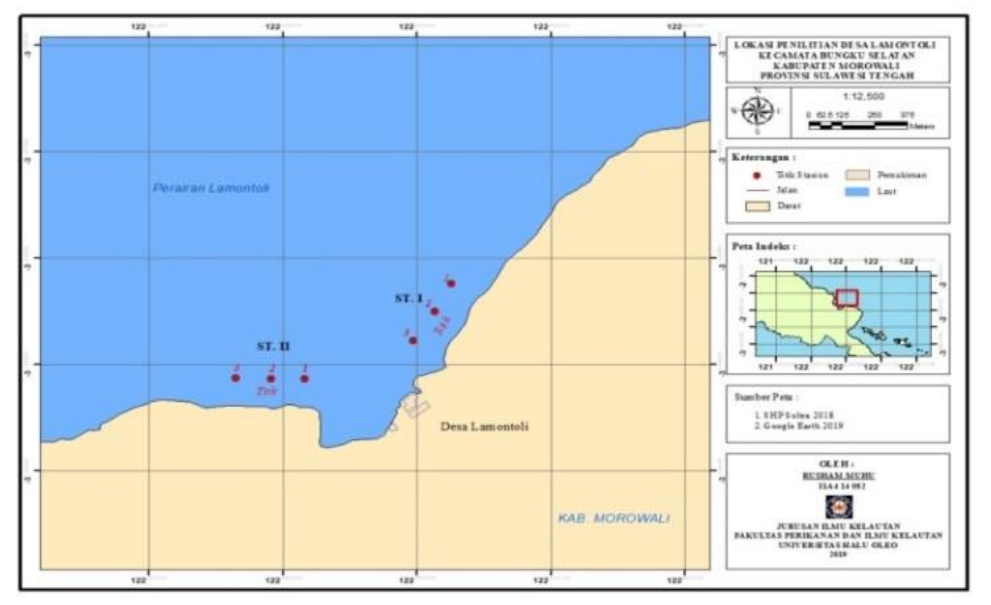

Gambar 1. Peta Lokasi Penelitian di Perairan Kawasan Lamontoli.

Tabel 1. Alat dan bahan yang digunakan pada saat pengambilan sampel data di lapangan.

\begin{tabular}{|c|c|c|c|c|}
\hline No & Alat dan Bahan & Satuan & Kegunaan & Jumlah Unit \\
\hline $\mathbf{A}$ & Alat & & & \\
\hline 1 & Thermometer & ${ }^{\circ} \mathrm{C}$ & Mengukur Suhu Perairan & 2 \\
\hline 2 & Secchi disk & Cahaya & Mengukur Kecerahan & 1 \\
\hline 3 & Handrefractometer & $\%$ & Mengukur Salinitas Perairan & 1 \\
\hline 4 & pH Indikator & - & Mengukur pH Perairan & 1 \\
\hline 5 & GPS & - & Mengambil Titi Koordinator & 2 \\
\hline 6 & Rol Meter & $\mathrm{m}$ & Memasang Transek & 1 \\
\hline 7 & Alat Tulis & - & Menulis HasilPenelitian & 2 \\
\hline 8 & Kamera & - & Dokumentasi Penelitian & 2 \\
\hline 9 & Lavangan Arus & $\mathrm{cm}$ & Mengukur Keepatan Arus & 1 \\
\hline 10 & Transek Kuadrat & $\mathrm{m}$ & Identifikasi Mangrove & 2 \\
\hline 11 & Patok Berskala & $\mathrm{m}$ & Mengukur Kedalaman & 1 \\
\hline B & Bahan & & & \\
\hline \multirow[t]{2}{*}{12} & Buku Identifikasi & - & Mengidentifakasi & \\
\hline & $\begin{array}{l}\text { Mangrove } \\
\text { (Dharmawan \& } \\
\text { Pramudji, 2014) }\end{array}$ & & Mangrove & 1 \\
\hline 13 & $\begin{array}{l}\text { Buku Identifikasi Ikan } \\
\text { (White } \text { et al., 2013) }\end{array}$ & - & Mengidentifikasi ikan & 1 \\
\hline 14 & Ikan & individu & Objek Pengamatan & \\
\hline
\end{tabular}

Metode pengambilan data ekosistem mangrove di Desa Lamontoli ini menggunakan metode sampling yaitu Metode Transek Garis dan Petak contoh (Transect Line Plot). Metode ini merupakan pencuplikan contoh populasi suatu ekosistem dengan pendekatan petak contoh yang berada pada garis yang ditarik melewati wilayah ekosistem tersebut, prosedur pengambilan data penelitian dilakukan pada 2 stasiun sampel secara purposive sampling methode dengan metoda pengukuran Transek Garis Berpetak (Ardhana, 2012).
Pengamatan mangrove menggunakan metode Line Transect. Transek garis ditarik dari titik acuan (pohon mangrove terluar) dengan arah tegak lurus garis pantai sampai ke daratan dengan panjang Line Transect 50 meter. Identifikasi jenis mangrove dapat langsung ditentukan di lapangan. Pada transek pengamatan dibuat petak-petak contoh untuk pengamatan dan identifikasi mangrove dengan mengacu pada Fachrul, (2007) yakni pohon memiliki diameter batang lebih besar dari $10-20 \mathrm{~cm}$ pada petak contoh 10 x 10 meter. Pancang yaitu anakan yang memiliki diameter batang kurang dari 
$10 \mathrm{~cm}$ dengan tinggi lebih dari 1,5 meter pada petak contoh 5 x 5 meter. Semai yaitu anakan mangrove yang memiliki tinggi kurang dari 1,5 meter pada petak contoh $1 \mathrm{x}$ 1 meter.

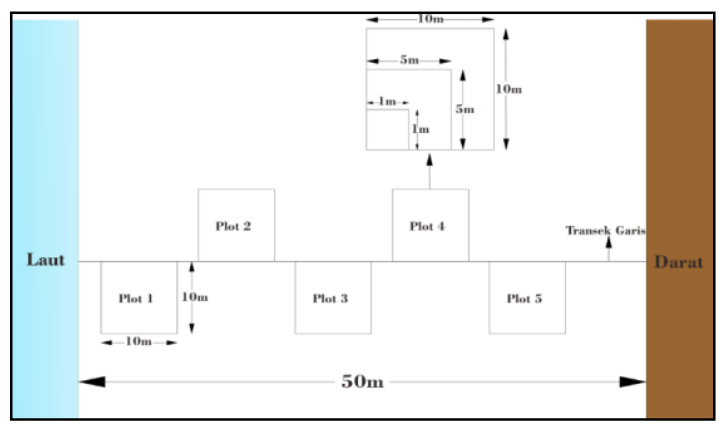

Gambar 2. Ilustrasi teknik pengambilan sampel mangrove

Pengamatan mangrove dilakukan dengan menggunakan metode transek kuadrat contoh yaitu dengan cara menarik garis lurus tegak lurus garis pantai disetiap stasiun, kemudian di atas garis tersebut ditempatkan kuadrat berukuran $10 \times 10$ meter sebagai substasiun contoh. Jarak antar kuadrat ditetapkan berdasarkan perbedaan struktur vegetasi. Masing-masing plot replikasi berada di dalam transek kuadrat berukuran $10 \times 10$ meter. Pada plot yang berukuran $10 \times 10$ meter dilakukan perhitungan jumlah pohon atau tegakan, dalam plot replikasi dibuat petak berukuran 5 x 5 meter untuk menghitung jumlah anakan dan petak berukuran 1 x 1 meter untuk mengukur jumlah semai. Setiap transek, lakukan identifikasi jenis tumbuhan mangrove, hitung jumlah pohon, anakkan dan semai serta ukur diameternya.

Pengambilan data ikan di perairan pada ekosistem mangrove dilakukan dengan menggunakan jaring insang. Pemasangan jaring insang berdasarkan variasi spasial yaitu enam titik lokasi pengambilan data dan terbagi dua, tiga titik di wilayah Timur dan tiga titik di wilayah Barat. Serta berdasarkan variasi temporal pemasangan jaring insang dilakukan satu kali pada siang hari saat air pasang menuju surut, pada malam hari saat air pasang menuju surut pula, pengambilan sampel dilakukan sebanyak 4 kali selama satu bulan, berdasarkan fase bulan. Menggunakan jaring insang memiliki mata jaring yang digunakan di lapangan berukuran (mesh size) 1,5 inci, panjang jaring 50 meter, tinggi jaring yaitu 1 meter.

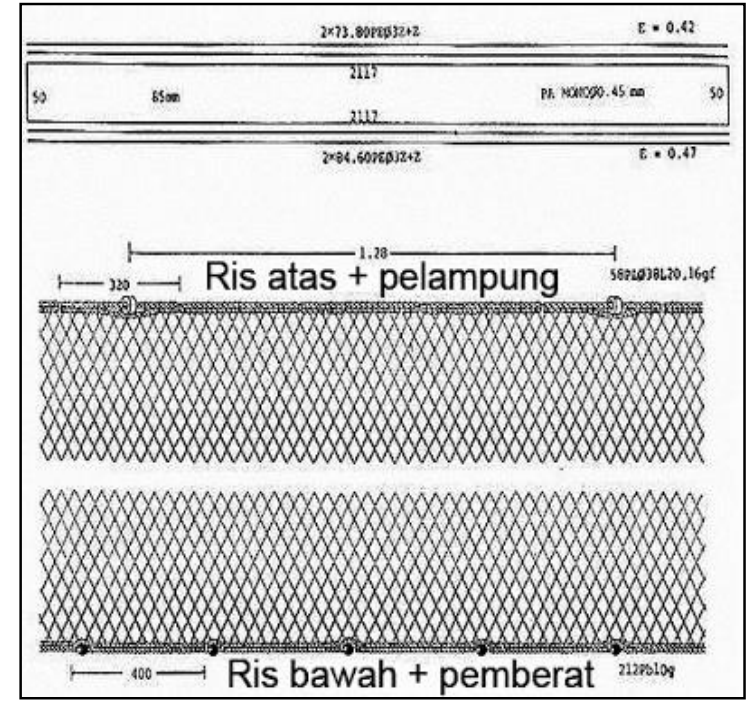

Gambar 3. Jaring Insang

Jaring yang digunakan berukuran (mesh size) 1,5 inci telah mewakili untuk melakukan penangkapan ikan. Pada siang hari untuk cara pemasangan jaring sendiri dilakukan pada saat pasang tertinggi menuju surut dengan menggunakan perahu, setelah dipasang untuk mendapatkan hasil yang maksimal kita perlu menunggu sampai surut terendah, begitu pun pada malam hari dan bulan gelap serta bulan terang.

Pengukuran kualitas perairan dilakukan pada setiap stasiun pengamatan yang meliputi pengukuran salinitas, suhu, kecepatan arus, $\mathrm{pH}$, kecerahan, kedalaman dan pasang surut. Parameter kualitas perairan selanjutnya diamati secara langsung di lapangan dan pengukuran kualitas perairan dilakukan sebanyak 3 kali ulangan pada tiap stasiun.

\section{Analisis Data}

Analisis kondisi ekosistem mangrove dimaksudkan untuk mengetahui persentase penutupan dan kerapatan pohon (pohon $/ \mathrm{m}^{2}$ ). Analisis ini menggunakan data hasil pengukuran langsung di lapangan, berupa jumlah individu, diameter batang, tipe substrat dan luas petak contoh yang diambil. Selanjutnya dilakukan analisis potensi, mengacu kepada English et al., 1994; Snedaker, (1984) :

Kerapatan jenis (Di) merupakan jumlah tegakan jenis ke-i dalam suatu unit area (Fachrul, 2007). Penentuan kerapatan jenis melalui rumus :

$\mathrm{Di}=\frac{N i}{A}$

Keterangan : 
$\mathrm{Di}=$ kerapatan jenis ke-i $(\%)$

$\mathrm{Ni}=$ jumlah total tegakan jenis ke-i

$\mathrm{A}=$ luas total area pengambilan contoh (m2)

Komposisi spesies adalah perbandingan antara jumlah individu setiap spesies dengan jumlah individu seluruh spesies yang tertangkap dengan formula yang dimodifikasi dari Fachrul (2007) : $\mathrm{Pi}=\frac{n i}{N} \times 100 \%$

Keterangan:

$\mathrm{Pi}=$ Komposisi spesies $(\%)$

$\mathrm{ni}=$ Jumlah spesies ke $-\mathrm{i}$

$\mathrm{N}=$ Jumlah total spesies.

Indeks keanekaragaman adalah nilai yang menjelaskan tingkat keseimbangan keanekaragaman dalam suatu pembagian jumlah individu tiap spesies. Rendah atau tingginya keanekaragaman spesies ikan dapat dilihat dengan menggunakan indeks keanekaragaman. Nilai indeks keanekaragaman Shannon (H') menurut Odum, (1993) dihitung menggunakan formula:

$\mathrm{H}^{\prime}=-\sum_{i=1}^{n}\{\mathrm{pi} \ln \mathrm{pi}\}, \mathrm{pi}=\mathrm{ni} / \mathrm{N}$

$\mathrm{H}^{\prime}=$ Indeks keanekaragaman ShannonWienner

pi $=$ Perbandingan antara jumlah individu spesies jenis ke-i dengan jumlah total individu spesies (ni/N)

$\mathrm{ni}=$ Jumlah individu spesies ke-i

$\mathrm{N}=$ Jumlah total indidvidu semua spesies

Penentuan kriteria:

$\mathrm{H}^{\prime}<1=$ Keanekaragaman rendah

$1<\mathrm{H}^{\prime}<3=$ Keanekaragaman sedang

$\mathrm{H}^{\prime}>3=$ Keanekaragaman tinggi

Indeks keseragaman adalah indeks yang menunjukan sebaran spesies disemua stasiun merata atau tidak dan mengetahui keseimbangan individu dalam keseluruhan populasi. Persamaan indeks keseragaman ikan dapat dihitung dengan rumus (Odum, 1993).

$\mathrm{E}=\frac{H^{\prime}}{H \max }$

Keterangan:

$\mathrm{E}=$ Indeks keseragaman

$\mathrm{H}^{\prime}=$ Indeks keanekaragaman ShannonWienner

$\mathrm{H}_{\max }=$ Indeks Keseragaman maksimum (In S)

$$
\text { Menurut Krebs, (1989) indeks }
$$

keseragaman berkisar antara 0-1

$\mathrm{E}<0,4=$ Keseragaman spesies rendah

$0,4 \leq \mathrm{E} \leq 0,6=$ Keseragaman spesies sedang

$\mathrm{E}>0,6=$ Keseragaman spesies tinggi
Nilai indeks dominansi (C) digunakan untuk melihat dominansi satu jenis ikan dalam komunitasnya. Formula indeks keseragaman menurut Odum, (1993) yaitu:

$\mathrm{C}=\sum_{i=1}^{n}\{\mathrm{ni} / \mathrm{N}\}^{2}$

Keterangan:

$\mathrm{C}=$ Indeks Dominansi Simpson,

ni $=$ Jumlah individu spesies ke-i

$\mathrm{N}=$ Jumlah individu seluruh spesies

\section{Hasil dan Pembahasan}

Kondisi lingkungan oseanografi mempengaruhi segala bentuk kehidupan yang ada di dalamnya, baik secara langsung maupun tidak langsung. Kondisi Perairan Lamontoli secara umum masih dalam keadaan baik untuk menunjang kehidupan mangrove dan ikan. Hal ini mengacu pada hasil pengukuran beberapa parameter yang masih berada dalam kisaran optimum untuk pertumbuhan mangrove dan ikan.

Ekosistem mangrove sangat rentan dan peka terhadap perubahan lingkungan hidup. Berbagai praktek pemanfaatan sumber daya alam yang hanya memperhatikan keuntungan jangka pendek seperti penebangan hutan mangrove untuk dijadikan perabotan rumah tangga, serta kegiatan pembangunan baik di darat maupun di laut yang tidak memperhatikan kelestarian lingkungan akan menyebabkan degradasi.

Kerapatan jenis mangrove pada stasiun 1 adalah 62 ind $/ 500 \mathrm{~m}^{2}$, kerapatan mangrove tertinggi yaitu jenis $R$. mucronata dengan kerapatan 42 ind/500 $\mathrm{m}^{2}$ dan kerapatan mangrove terendah yaitu jenis $S$. alba 16 ind/500 $\mathrm{m}^{2}$ sedangkan pada stasiun 2 kerapatan jenis mangrove adalah $81 \mathrm{ind} / 500$ $\mathrm{m}^{2}$, kerapatan mangrove tertinggi yaitu jenis $R$. mucronata dengan kerapatan $56 \mathrm{ind} / 500$ $\mathrm{m}^{2}$, jenis mangrove $R$. apiculata $20 \mathrm{ind} / 500$ $\mathrm{m}^{2}$ dan jenis kerapatan mangrove terendah yaitu $S$. alba 5 ind $/ 500 \mathrm{~m}^{2}$. Pada stasiun 1 kerapatan mangrovenya dapat di kategorikan sedang dan pada stasiun 2 kerapatan mangrovenya berada pada kategori sangat padat, hal ini sesuai dengan kriteria baku kerusakan mangrove dengan menggunakan kriteria kerapatan (pohon/ha) sangat padat $\geq 1500$, kriteria sedang $\geq 1000$ - $<1500$ dan kritera jarang < 1000 (KLHK, 2004). 
Tabel 2. Nilai parameter fisika, kimia perairan pada stasiun penelitian di Perairan Lamontoli.

\begin{tabular}{lllll}
\hline \multirow{2}{*}{ Parameter } & \multicolumn{2}{c}{ Fase Bulan Gelap } & \multicolumn{2}{c}{ Fase $\mathbf{1 / 4}$ Bulan Gelap } \\
\cline { 2 - 5 } & Stasiun 1 & Stasiun 2 & Stasiun 1 & Stasiun 2 \\
\hline Suhu $\left({ }^{\circ} \mathrm{C}\right)$ & 31,6 & 31,2 & 31 & 30,6 \\
Salinitas (ppt) & 31,3 & 30,8 & 29,7 & 29,4 \\
pH & 7 & 7 & 7 & 7 \\
Kecepatan Arus (m/s) & 0,14 & 0,16 & 0,096 & 0,1 \\
Kedalaman (cm) & 178,5 & 183,8 & 143,4 & 151,9 \\
Kecerahan $(\%)$ & 100 & 100 & 100 & 100 \\
\hline
\end{tabular}

Tabel 3. Nilai parameter fisika, kimia perairan pada stasiun penelitian di Perairan Lamontoli.

\begin{tabular}{lllll}
\hline \multirow{2}{*}{ Parameter } & \multicolumn{2}{c}{ Fase Bulan Terang } & \multicolumn{2}{c}{ Fase 1/4 Bulan Terang } \\
\cline { 2 - 5 } & Stasiun 1 & Stasiun 2 & Stasiun 1 & Stasiun 2 \\
\hline Suhu $\left({ }^{\circ} \mathrm{C}\right)$ & 31,8 & 31,5 & 30,2 & 29,7 \\
Salinitas (ppt) & 31,4 & 31,1 & 29,5 & 28,6 \\
pH & 7 & 7 & 7 & 7 \\
Kecepatan Arus (m/s) & 0,11 & 0,13 & 0,105 & 0,125 \\
Kedalaman $(\mathrm{cm})$ & 169,8 & 173,7 & 149,2 & 154,6 \\
Kecerahan $(\%)$ & 100 & 100 & 100 & 100 \\
\hline
\end{tabular}

Stasiun 2 memiliki substrat yang sangat sesuai dengan jenis $R$. mucronata yaitu lumpur lunak. Menurut Hogarth, (1999) lumpur adalah unsur yang sangat penting dalam ekosistem mangrove sedangkan mangrove yang memiliki kerapatan jenis terendah yaitu dengan mangrove jenis $S$. alba yang terdapat pada stasiun 1. Jenis mangrove tumbuh di areal dengan salinitas rendah dan tanah yang kering.

Menurut Noor, (1999) R. mucronata hidup pada substrat pasir berlumpur, tumbuh pada area yang sama dengan $R$. apiculata tetapi lebih toleran terhadap substrat yang lebih keras dan pasir. Pada umumnya, tumbuh dalam kelompok, dekat atau pada pematang sungai pasang surut dan di muara sungai, jarang sekali tumbuh pada daerah yang jauh dari air pasang surut.

Hasil penelitian, kualitas fisika dan kimia habitat mangrove di Perairan Desa Lamontoli memiliki rata-rata $\mathrm{pH}$ air berkisar 7. Hal tersebut menunjukkan bahwa $\mathrm{pH}$ perairan masih netral bagi vegetasi mangrove dan biota perairan. Menurut Koch, (2001) pH berhubungan erat dengan aktivitas dekomposer.

Stasiun 1 jenis ikan yang dominan tertangkap pada fase bulan gelap yaitu $L$. subrividis dengan komposisi jenis $26 \%$ sedangkan jenis ikan yang paling sedikit tertangkap pada stasiun 1 yaitu $C$. melampygus dan $U$. vittatus yakni sekitar 1
$\%$. Pada $1 / 4$ bulan terang, ikan yang banyak tertangkap adalah L. subrividis yakni $34 \%$, sedangkan Jenis ikan yang paling sedikit tertangkap pada stasiun 1 yaitu $U$. trangula, $U$. vittatus dan A. blakeeri yakni sekitar $1 \%$. Pada bulan terang ikan yang banyak tertangkap adalah L. subrividis yakni $30 \%$, sedangkan jenis ikan yang paling sedikit tertangkap pada stasiun 1 yaitu $U$. tranula, $U$. vittatus dan G. flimantosus yakni $1 \%$. $\%$. Pada $1 / 4$ bulan gelap, ikan yang banyak tertangkap adalah L. subrividis yakni $38 \%$ sedangkan jenis ikan yang paling sedikit tertangkap pada stasiun 1 yaitu $S$. strongylura yakni sekitar $1 \%$.

Stasiun 2 jenis ikan yang dominan tertangkap pada fase bulan gelap yaitu $L$. subrividis dengan komposisi jenis $15 \%$, sedangkan jenis ikan yang paling sedikit tertangkap pada stasiun 2 yaitu $U$. vittatus yakni sekitar $1 \%$. Pada $1 / 4$ bulan terang, ikan yang banyak tertangkap adalah $L$. vubrividis yakni $28 \%$ sedangkan jenis ikan yang paling sedikit tertangkap pada stasiun 2 yaitu, $U$. vittatus dan G. flimantosus yakni sekitar $1 \%$. Pada bulan terang ikan yang banyak tertangkap adalah L. subrividis yakni $32 \%$ sedangkan jenis ikan yang paling sedikit tertangkap pada stasiun 2 yaitu, $U$. trangula dan yakni $1 \%$. \%. Pada $1 / 4$ bulan gelap, ikan yang banyak tertangkap adalah $L$. subrividis dan $G$. flimantosus yakni $24 \%$, sedangkan jenis ikan yang paling sedikit tertangkap pada stasiun 2 yaitu T. jarbau yakni sekitar $1 \%$. 
Tabel 4. Kerapatan jenis Mangrove pada tiap stasiun penelitian di kawasan mangrove Lamontoli

\begin{tabular}{cccc}
\hline \multirow{2}{*}{ No } & \multirow{2}{*}{ Jenis Mangrove } & \multicolumn{2}{c}{ Kerapatan Jenis Mangrove (Tegakan/ $\mathbf{m}^{\mathbf{}}$ ) } \\
\cline { 3 - 4 } & Soneratia alba & 0,16 & Stasiun II \\
\hline 1 & Rizophora Mucronata & 0,46 & 0,05 \\
2 & Rizophora Apiculata & 0,62 & 0,61 \\
3 & Total & 0,15 \\
\hline \multicolumn{2}{c}{}
\end{tabular}

Tabel 5. Jenis ikan yang tertangkap pada stasiun penelitian berdasarkan variasi spasial dan temporal di Perairan Lamontoli.

\begin{tabular}{|c|c|c|c|}
\hline Kelas & Ordo & Famili & Spesies \\
\hline Actinopterygii & Percomorphi & Gerreidea & $\begin{array}{l}\text { Gerres flimantosus } \\
\text { Gerres oyona }\end{array}$ \\
\hline Actinopterygii & Beloniformes & Bolonidae & Strongylura strongylura \\
\hline Pisces & Perchomorphi & Leiognatidae & $\begin{array}{l}\text { Gaza minunta } \\
\text { Leiognathus fasciatus }\end{array}$ \\
\hline Pisces & Colombiformes & Toxotidae & Toxotes jaculatrik \\
\hline Actinopterygii & Mugiliformes & Mungilidae & Liza subrividis \\
\hline Actinopterygii & Perciformes & Carangidae & $\begin{array}{l}\text { Caranx sexfaciatus } \\
\text { Caranx melampygus }\end{array}$ \\
\hline Actinopterygii & Perciformes & Mullidae & $\begin{array}{l}\text { Upneus trangula } \\
\text { Upneus vittatus }\end{array}$ \\
\hline Actinopterygii & Kurtiformes & Apogonidea & $\begin{array}{l}\text { Sphaeramia orbicularis } \\
\text { Archamia bleekeri }\end{array}$ \\
\hline Actinopterygii & Perciformes & Singanidae & Sigganus guttatus \\
\hline Pisces & Colombiformes & Terapontidae & Terapon jarbau \\
\hline
\end{tabular}

Septiarusli, (2010) menyatakan bahwa mangrove dapat tumbuh dengan baik pada salinitas air payau antara 2-22\%o atau air asin dengan salinitas mencapai $38 \%$. Pada stasiun 1 dan 2 memiliki nilai salinitas rata-rata yang tergolong baik berkisar antara 29,97-30,57\% . Meskipun menunjukkan nilai yang cukup tinggi tetapi salinitas yang terdapat di perairan tersebut masih cukup sesuai untuk tempat tumbuh mangrove.

Rata-rata suhu perairan pada stasiun 1 dan 2 berkisar antara $30,75-31,15^{\circ} \mathrm{C}$. Kisaran suhu tersebut termasuk baik untuk pertumbuhan mangrove. Alongi, (2009) menyatakan bahwa konduktansi stomata dan laju asimilasi pada daun mangrove yang maksimal berkisar pada suhu $25-30^{\circ} \mathrm{C}$ dan akan mengalami penurunan yang cepat pada suhu di atas $35^{\circ} \mathrm{C}$ untuk jenis Rhizophora, proses fotosintesis paling cepat pada suhu $25^{\circ} \mathrm{C}$ dan akan menurun tajam pada suhu di atas $35^{\circ} \mathrm{C}$ (Hogarth, 2007). Selain akan mepengaruhi proses fisiologi tumbuhan mangrove, suhu perairan juga dapat mepengaruhi kegiatan hewan air seperti migrasi, pemangsaan, kecepatan berenang, perkembangan embrio dan kecepatan proses metabolisme (Cahyani, 2001). Terdapat beberapa hal yang mepengaruhi tingginya suhu, antara lain intensitas sinar matahari yang secara langsung jika kawasan mangrove agak terbuka karena jarak agak besar.

Hasil penelitian pada stasiun 1 terdapat 2 jenis mangrove yaitu $S$. alba dan $R$. mucronata pada ptasiun ini di dominansi oleh jenis $R$. mucronata dan pada stasiun 2 terdapat 3 jenis mangrove yaitu $S$. alba, $R$. mucronata dan $R$. apiculata, juga di dominasi oleh $R$. mucronata.

Tingginya kerapatan jenis mangrove menunjukkan banyaknya tegakan pohon yang berada dalam kawasan tersebut. $R$. mucronata memiliki kerapatan mangrove tertinggi pada semua kategori. Kondisi ini disebabkan karena jenis $R$. mucronata ini merupakan jenis mangrove yang pertumbuhannya toleran terhadap kondisi lingkungan, terutama terhadap kondisi substrat, serta penyebaran bijinya yang sangat luas. Hal ini sesuai dengan pendapat Kartawinata, (1979) bahwa jenis $R$. mucronata merupakan salah satu jenis 
tumbuhan mangrove yang toleran terhadap kondisi lingkungan (seperti substrat, pasang surut, salinitas dan pasokan nutrien) dapat menyebar luas dan dapat tumbuh tegak pada berbagai tempat.

Menurut Noor et al., (1999) $R$. mucronata tumbuh pada areal yang sama dengan R.apiculata tetapi lebih toleran terhadap substrat yang lebih keras dan pasir. Pada umumnya tumbuh dalam kelompok dekat atau pada pematang sungai pasang surut dan di muara sungai, jarang sekali tumbuh pada daerah yang jauh dari air pasang surut.

Pada dua stasiun tersebut juga terdapat jenis mangrove $S$. alba karena terdapat daerah aliran sungai musiman yang terdapat air tawar pada saat musim hujan, ini sesuai dengan pernyataan Noor et al., (1999) menyatakan bahwa $S$. alba adalah jenis tumbuhan pionir yang toleran terhadap air tawar dalam periode lama, menyukai tanah yang bercampur lumpur dan pasir, kadangkadang pada batuan dan karang.

Sedikitnya komposisi jenis mangrove di daerah pengamatan disebabkan mangrove sudah mengalami kerusakan terutama akibat penebangan hutan mangrove untuk di jadikan kayu bakar(Sukardjo, 1996).

Kondisi ekosistem mangrove di lokasi penelitian didominasi oleh vegetasi jenis $R$. mucronata. Secara umum ekosistem mangrove memperlihatkan adanya pola zonasi yang berkaitan erat dengan tipe tanah, keterbukaan, salinitas serta pengaruh pasang surut. Tipe tanah dengan substrat berlumpur sangat baik untuk tegakan $R$. mucronata dan diduga tekstur tanah di lokasi penelitian merupakan kondisi yang cocok bagi pertumbuhan dan perkembanagan tegakan $R$. mucronata. Selain itu $R$. mucronata mampu tumbuh pada salinitas yang tinggi hingga 55\%o (Noor et al., 1999), pertumbuhan $R$. mucronata sering mengelompok karena propagul yang sudah matang akan jatuh dan langsung menancap ke tanah (Suryawan, 2007). Gunawan dan Anwar, (2005) menambahkan perbedaan kondisi hutan mangrove pada tiap lokasi dapat disebabkan oleh hama dan penyakit tanaman, gangguan ternak, gangguan manusia, tingkat kesuburan serta kesesuaian tempat tumbuh.

Jenis mangrove $R$. apiculata merupakan jenis yang paling sedikit di temukan pada saat penelitian karena substrat yang komposisi lumpurnya rendah atau berkarakter keras dan cenderung kasar (pasir, pasir berlumpur dan pasir berbatu). Spesies ini umumnya tumbuh pada tanah berlumpur, halus, dalam dan tergenang pada saat pasang normal. R. apiculata tidak menyukai substrat yang keras (Noor et al., 1999).

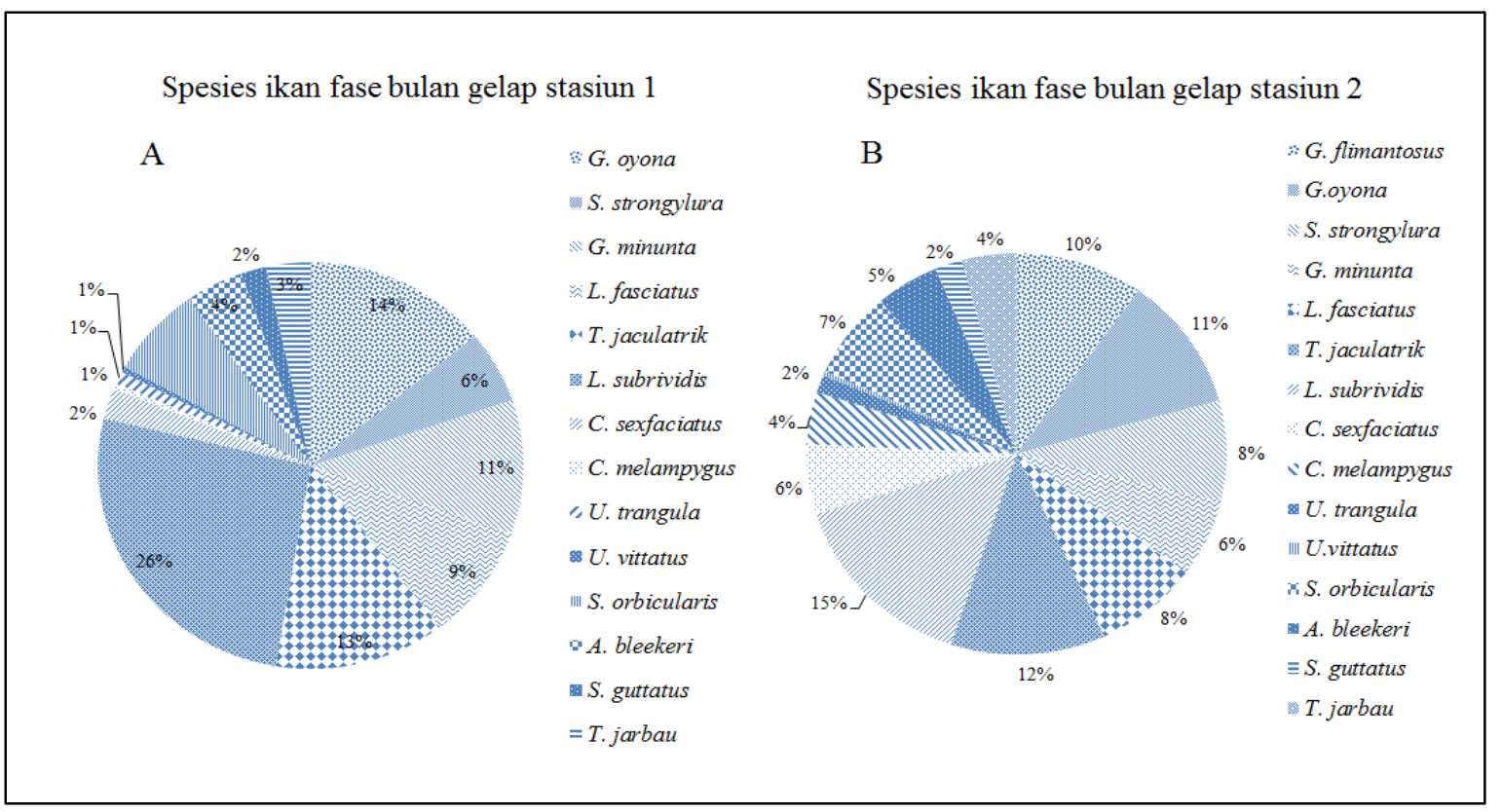

Gambar 4. Komposisi jenis ikan pada setiap stasiun penelitian pada fase bulan gelap. 


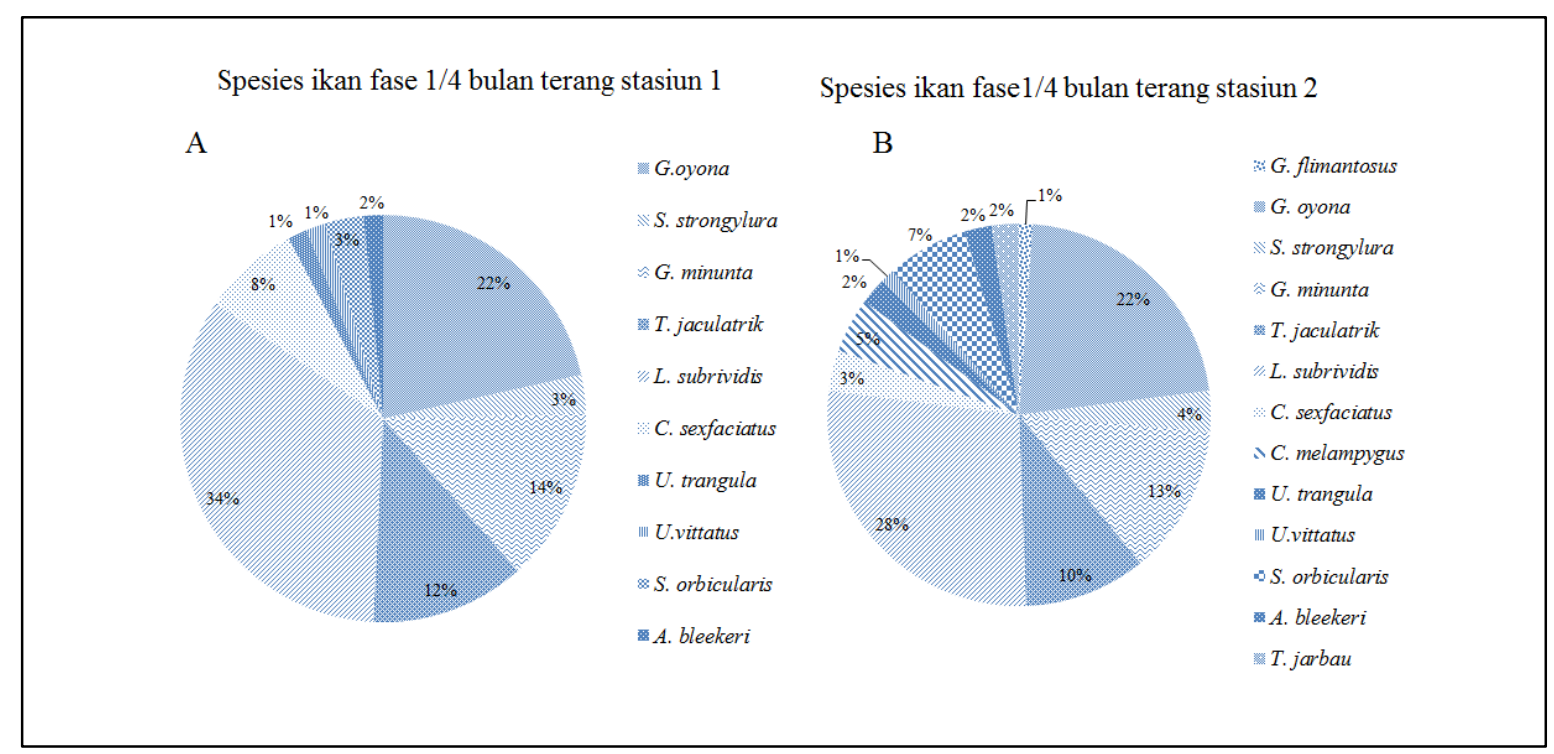

Gambar 5. Komposisi jenis ikan pada setiap stasiun penelitian pada fase $1 / 4$ bulan terang

Hasil penelitian yang dilakukan selama bulan September 2018 diperoleh jumlah total individu ikan secara temporal yang tertangkap berdasarkan fase bulan gelap berjumlah 492 individu, fase $1 / 4$ bulan terang berjumlah 152 individu, fase bulan terang berjumlah 355 dan pada $1 / 4$ bulan gelap 86 individu. Komposisi masing-masing spesies tersaji dalam gambar 4 dan 5 .

Analisis hubungan kerapatan mangrove dengan komposisi jenis ikan secara statistik (Regresi Linear) menunjukkan bahwa tingginya kelimpahan ikan sangat dipengaruhi oleh tingginya kerapatan mangrove .

Secara keseluruhan, kerapatan mangrove dengan jumlah tangkapan ikan, jumlah jenis ikan dan keanekaragaman ikan memiliki hubungan positif. Ini menunjukkan bahwa semakin tinggi kerapatan pohon mangrove, semakin tinggi jumlah tangkapan ikan, jumlah jenis ikan dan keanekaragamn ikan. Hal tersebut sesuai dengan pernyataan Baran, (1999) yang melakukan penelitian di Teluk Meksiko terdapat hubungan positif antara penangkapan ikan yang dilakukan secara komersil dan wilayah pesisir yang ditumbuhi mangrove. Baran, (1999) juga menunjukkan adanya korelasi antara luasan mangrove di Vietnam dan hasil penagkapan ikan. Sehubungan dengan hal tersebut, dapat dikatakan bahwa ekosistem mangrove memiliki peran penting sebagai habitat ikan.

Hasil pengamatan mangrove tertinggi berada pada stasiun 2 yaitu $81 \mathrm{ind} / 500 \mathrm{M}^{2}$ dan kerapatan lebih rendah terdapat pada stasiun 1 yaitu 62 ind/500 $\mathrm{M}^{2}$. Begitu pula pada keanekaragaman jenis ikan tertinggi di stasiun $2(2,512)$ yang merupakan stasiun dengan keanekaragaman yang lebih tinggi dan keanekaragaman paling rendah yaitu pada stasiun $1(1,755)$.

Hal tersebut dapat dilihat pada hasil persamaan regresi antara kerapatan mangrove dengan keanekaragaman jenis ikan pada fase bulan gelap, dimana nilai $\mathrm{y}=0.5291 \mathrm{x}+0.0058$, fase $1 / 4$ bulan gelap $y=2.564 x-0.2179$, fase bulan terang $\mathrm{y}=0.8418 \mathrm{x}-0.0135$, fase $1 / 4$ bulan terang $\mathrm{y}=1.5432 \mathrm{x}-0.0664$ dan koefisien determinasi $\mathrm{R}^{2}=1$.

Keanekaragaman jenis ikan di Perairan Desa Lamontoli dipengaruhi oleh kerapatan mangrove dan menggambarkan hubungan positif, dengan demikian struktur komunitas ikan yang terdapat pada setiap stasiun penelitian di Perairan Desa Lamontoli dipengaruhi oleh adanya vegetasi mangrove. Ikejima et al., (2003) mengemukakan bahwa spesies ikan remaja ekonomis penting lebih dari $76 \%$ individu diperoleh dari hutan mangrove. Harahap, (2009) menyatakan bahwa korelasi kuat antara beberapa variabel dicapai apabila nilai $\mathrm{R}$ (koefisien korelasi) lebih besar dari 0,5. Berdasarkan hasil analisa korelasi antara kerapatan mangrove dengan keanekaragaman jenis ikan dapat terlihat bahwa nilai $\mathrm{R}$ adalah sebesar 1 lebih besar dari 0,5 . 

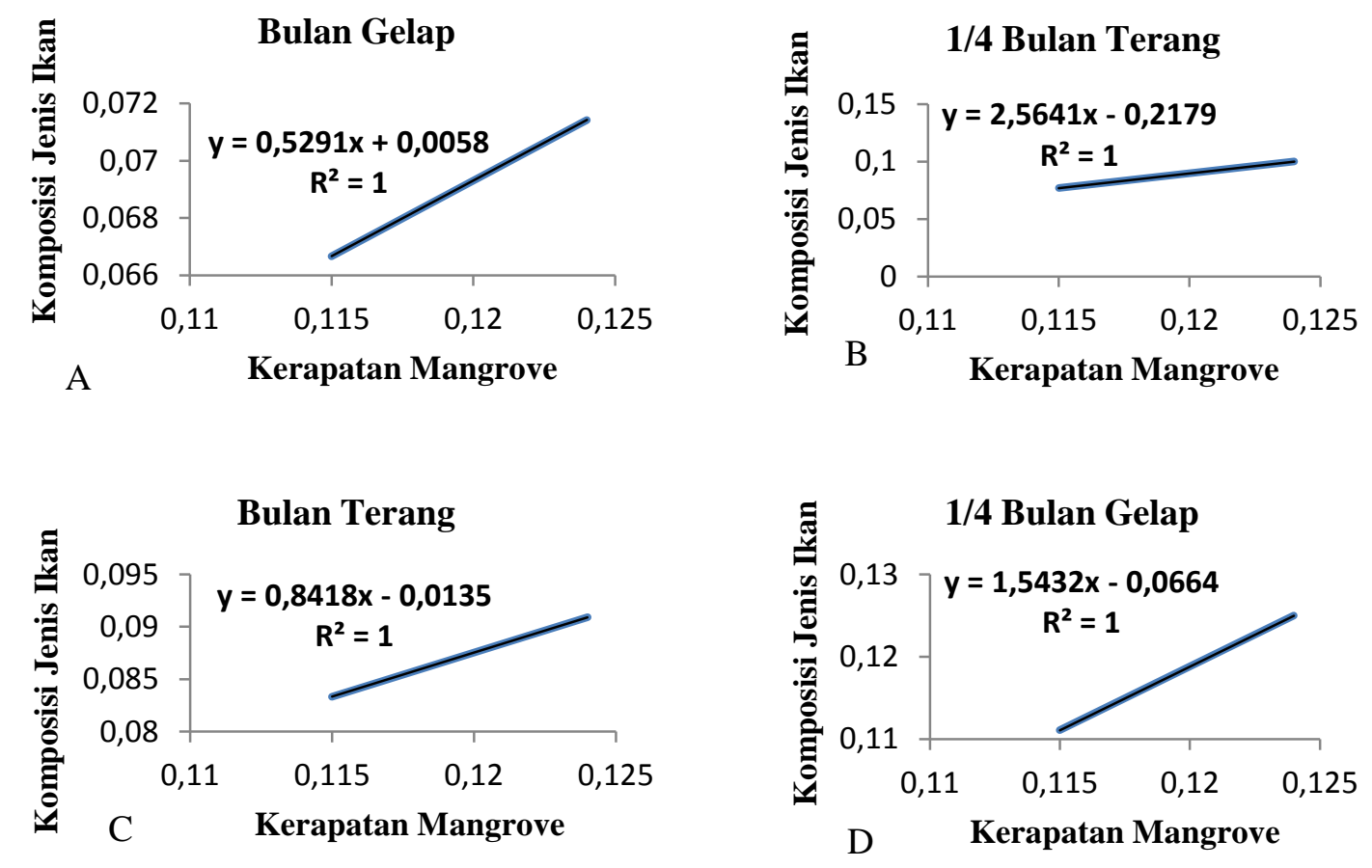

Gambar 11. Analisis regresi linear kerapatan mangrove dan komposisi jenis ikan (A) fase bulan gelap (B) fase $1 / 4$ bulan terang (C) fase bulan terang (D) fase $1 / 4$ bulan gelap di Perairan Lamontoli.

Ikan yang tertangkap di Perairan Desa Lamontoli juga di pengaruhi oleh perbedaan fase bulan dimana ikan yang tertangkap lebih banyak pada fase bulan gelap yaitu $45 \%$, fase $1 / 4$ bulan terang $14 \%$, fase bulan terang $35 \%$ dan fase $1 / 4$ bulan gelap $8 \%$. Hasil pengamatan ini menunjukkan begitu signifikannya sebaran ikan dengan fase bulan yang juga mempengaruhi pasang surut air laut.

Melimpahnya jenis-jenis ikan dan jumlah yang tertangkap fase bulan gelap dan terang (pasang purnama) disebabkan daerah perairan yang dipengaruhi massa air laut maupun air tawar akibat proses pasang surut menyebabkan distribusi ikan baik dari laut maupun dari perairan tawar banyak ditemukan pada daerah ini dan area ini sangat unik yang ditengarai oleh fluktuasi salinitas dan genangan air laut sepanjang hari (Tampubolon et al., 2018). Lebih lanjut, Reis-Filho et al., (2010) menjelaskan jumlah spesies, individu, kekayaan dan keanekaragaman secara signifikan lebih tinggi pada bulan purnama dari pada di bulan perbani (pasang perbani). Kehadiran jenisjenis ikan di suatu perairan.

Selama penelitian juga dipengaruhi oleh musim yang secara langsung berpengaruh terhadap kondisi lingkungan dan sebaran ikan pada stasiun penelitian. Hal ini dijelaskan oleh Karuwal \& Bagafih, (2016) bahwa ikan bereaksi secara langsung terhadap perubahan lingkungan yang dipengaruhi oleh kecepatan arus dengan cara mengarahkan dirinya secara langsung pada arus dan umumnya gerakan ikan selalu mengikuti arah menuju arus. Arus yang terjadi pada perairan Desa Lamontoli adalah arus akibat proses pasang surut yang dapat mendistribusikan parameter fisika-kimia perairan dalam periaran dan jenis-jenis ikan, hal ini sesuai dengan pernyataan Ono \& Addison, (2009) bahwa siklus bulan berhubungan dengan siklus bulan pasang surut yang memiliki hubungan kuat.

Famili yang paling banyak diperoleh selama dilakukan penelitian adalah famili mugilidae yang ditemukan di setiap titik stasiun dan di semua fase bulan. Salah satu jenis ikan yang banyak dijumpai di Indonesia yang berasal dari famili mugilidae adalah ikan belanak. Famili mugilidae merupakan larva ikan yang paling sering dijumpai dan berhasil tertangkap oleh jaring, diduga karakteristik pergerakan ikan mugilidae yang sering menggerombol dan berada di permukaan sampai kolom air. Menurut Redjeki, (2013) 
famili mugilidae termasuk dalam kelompok ikan yang mempunyai kemampuan adaptasi cukup baik sehingga larva ikan ini dapat ditemukan hampir di semua perairan, ikan belanak merupakan ikan yang berasosiasi dengan hutan mangrove selama periode larva dan juvenil tetapi pada saat dewasa cenderung menggerombol di sepanjang pantai yang berdekatan dengan hutan mangrove. Hal ini sesuai dengan kebiasaan makan ikan dari family mungilidae salah satu jenisnya adalah L. subrividis sehingga dapat disimpulkan bahwa hubungan sangat erat antara luas hutan mangrove dan perbedaan fase bulan dengan keanekaragaman jenis ikan di Perairan Desa Lamontoli.

\section{Kesimpulan}

1. Komposisi jenis ikan terbanyak pada vegetasi mangrove yang padat dan jumlah tangkapan ikan terbanyak pada fase bulan gelap sedangkan jenis ikan yang sedikit pada vegetasi mangrove yang sedang dan jumlah tangkapan sedikit pada fase $1 / 4$ bulan gelap.

2. Keanekaragaman jenis ikan tertinggi pada daerah mangrove kategori padat di bandingkan daerah mangrove yang kategori sedang, pada fase bulan gelap keseragaman tertinggi pada fase $1 / 4$ bulan gelap dan dominansi tertinggi pada fase $1 / 4$ bulan gelap pada daerah yang relatif sedang.

3. Kerapatan mangrove yang tinggi memiliki hubungan yang erat dengan komposisi jenis ikan yang tertangkap baik secara spasial dan temporal.

\section{Daftar Pustaka}

Alongi DM. 2009. The energetics of mangrove forests. Springer, Australia

Ardhana, I.P.G. 2012. Ekologi Tumbuhan. Udayana University Press. Universitas Udayana. Denpasar.

Barletta, M., A. Barletta-Bergan, U. Saint-Paul, \& G. Hubold. 2003. Seasonal changes in density, biomass, and diversity of estuarine fishes in tidal mangrove creeks of the lower Caeté Estuary. Mar. Ecol. Prog. Ser. 256:217-228.

Blaber, S. J. M. 1997. Fish and fisheries of tropical estuaries. Chapman \& Hall. London
Brower JE, Zar JH \& von Ende CN. 1990. Field and Laboratory methods for general ecology. 3rd edition.Wm. C. Brown Publishers. Dubuque, IA.

Carpenter, K.E., V.H. Niem. 1999a. FAO species identification guide for fishery purposes. the living marine resources of the Western Central Pacific. Vol. 3. Batoid Fishes, Chimaeras and Bony Fishes part 1 (Elopidae to Linophrynidae).

Carpenter, K.E., V.H. Niem. 1999b. FAO Species identification guide for fishery purposes. The Living Marine Resources of The Western Central Pacific. Vol. 4. Batoid Fishes part 2 (Mugilidae to Caragidae).

Chaerani, N. 2011. Kerapatan, Frekuensi dan Tingkat Penutupan Jenis Mangrove di Desa Coppo Kecamatan Barru Kabupaten Barru. Skripsi. Universitas Hasanuddin. Makassar.

Collette, B.B., 2003. Famili Belonidae Bonaparte 1832-needlefishes. Calif. Acad. Sci. Annotated Checklists of Fishes. 16: 22.

English, S., C. Wilkinson and V. Baker, 1994. Survey Manual for Tropical Marine Resources. Published on Behalf of the ASEAN-Australia Marine Science. Townswile. pp 367.

Fachrul, M.F. 2007. Metode Sampling Bioekologi. BumiAksara. Jakarta.

Firhansyah. 2005. Pola Kebiasaan Makanan (Food Habits) Famili Mugilidae yang Tertangkap dengan Pukat Pantai (Beach Seine) di Muara Sungai Hanyar

Gundermann N., Popper D.M., Lichatowich T. 1983. Biology and Life Cycle of Siganusvermiculatus (Siganidae, Pisces). Pacific Sci. 37 (2): 165-180

Halidah. 2007. Ekosistem Mangrove dan Peranannya dalam Kelestarian Kawasan Pantai. Info Hutan. 4.

Harahap,N. 2009. Pengaruh Ekosistem Hutan Mangrove Terhadap Produksi Perikanan Tangkap. Studi Kasus Di Kabupaten Pasuruan, Jawa Timur. Jurnal Perikanan (J. Fish. Sci.) XI (1): 100-106.

Huang, L., D. Huang, Z. Wu, B. Kang, Z. Chen. 2016. Temporal Variation of Fish Diversity and Assemblages and their Associations to Environmental Variables in the Mangrove of Qinzhou Harbor, Guangxi Province, China. Turkish 
Journal of Fisheries and Aquatic Sciences, 16: 297-310.

Hutomo M. dan M. H. Azkab. 1987. Peranan Lamun di Lingkungan Laut Dangkal. Oseana, 12(1): 13-23.

Hogarth PJ. 2007. The biology of mangroves and seagrasses - Second edition. Oxford University Press, New York.

Ikejima, K., Tongnunui, P., Medej, T., Taniuchi, T., 2003. Juvenile and Small Fishes in a Mangrove Estuary in Trang Province, Thailand: Seasonal and Habitat Differences. Estuarine, Coastal and Shelf Science 56 (34), pp447-457.

Ismen A. 2005. Age, growth, and reproduction of the goldband goatfish Upeneus moluccensis (Bleeker, 1855) in Iskenderun Bay, the Eastern Mediterranean. Journal of Zoology Turkey. 29: 301-309.

Kartawinata, K., S. Adisoemodiharjo dan I. G. M. Tantra. 1979. Status Pengetahuan Hutan Bakau Indonesia. Prosiding Seminar Ekosistem Mangrove. LIPIMAB: 21 - 39. Jakarta.

Karuwal, J. dan A. Bagafih.2016. Pengaruh Periode Hari Bulan Terhadap Hasil Tangkapan Ikan Teri (Stelophorus spp) Dan Kaitannya Dengan Faktor Fisik Perairan Pada Bagan Perahu. Jurnal Agroforestri XI Nomor 3: 177-187.

Kathiresan, K dan Bingham, B. L. 2001. Biology Of Mangroves and Mangrove Ecosystems. Advances in Marine Biology. Vol. 40 (81-251).

KLH. 2004. Kriteria Baku dan Pedoman Penentuan Kerusakan Mangrove. Jakarta: Keputusan Menteri Lingkungan Hidup No.201.

Latuconsina H, Nessa MN, Ambo-Rappe R.2012. Komposisi spesies dan struktur ko-munitas ikan padang lamun perairanTan-jung Tiram-Teluk Ambon Dalam.Ilmu danTeknologi $\mathrm{K}$ elautan Tropis,4(1): 35-46.

Manoharan J, Gopalakhrisnan A, Varadharajan D, Thilagavathi B, Priyadharsini S. 2012. Stomach content analysis of Terapon jarbua (Forsskal) from Parangipettai

Coast, South East Coast of India. Advances in Applied Science Research, 3(5): 26052621.

Marasabessy, M.D. 1991. Penelitian Budidaya Ikan Samadar (Siganus Canaliculatus) di
Pulau-Pulau Kai Kecil, Maluku Tenggara. Eds Perairan Maluku Tenggara. Ambon: Balitbang Sumberdaya Laut, Puslitbang Oseanografi LIPI. Hlm : 35-41.

Merryanto, Y. 2000. Struktur Komunitas Ikan dan Asosiasinya dengan Padang Lamun di Perairan Teluk Awur Jepara. [Tesis] Bogor: Sekolah Pascasarjana Institut Pertanian Bogor. Hlm 39-46.

Noor, Y. R, M. Khazali, \& I N.N. Suryadiputra. $1999 . \quad$ Panduan Pengenalan Mangrove di Indonesia. PKA/Wi-IP, Bogor. viii + 220 p.

Odum, E. P. 1993 Dasar-Dasar Ekologi. Yogyakarta, Gajah Mada University Press.

Ono,R. and D.J. Addison. 2009. Ethnoecology and Tokelauan fishing lore from Atafu Atoll, Tokelau. SPC Traditional Marine Resource Management and knowledge Information Bulletin 26: 3 -22.

Reis-Filho,J.A., F.Barros, J.D.A.C.D.C. Nunes, C.L.S.Sampaio, and G.B.G.D. Souza. 2010. Moon And Tide Effects On fish Capture In A Tropical Tidal flat. Journal of the Marine Biological Association of the United Kingdom, page 1 of 9

Redjeki, S. 2013. Komposisi dan Kelimpahan Ikan di Ekosistem Mangrove di Kedung malang Jepara. Ilmu Kelautan, 18(1): $54-60$.

Rejeki, S., Irwani., F.M. Hisyam. 2013. Struktur komunitas ikan pada ekosistem mangrove di Desa Bedono, Sayung, Demak. Jurnal Buletin Oseanografi Marin, $2: 78-86$.

Robertson, AI. \& SJM. Blaber. 1992. Plankton, epibenthos and fish communities. In: Robertson AI, Alongi DM (eds) Tropical mangrove ecosystems. American Geophysical Union, Washington, DC, p 173-224.

Satria, G.G.A. dkk,. 2014. Kelimpahan Jenis Teripang Di Perairan Terbuka Dan Perairan Tertutup Pulau Panjang Jepara, Jawa Tengah. Universitas Diponegoro. Semarang.

Septiarusli IE. 2010. Ekosistem Mangrove di Jawa Barat.

Setyawan, A. D. 2002. Ekosistem Mangrove Sebagai Kawasan Peralihan Ekosistem Perairan Tawar dan Perairan Laut. Enviro. 2 (1) : 25-40. 
Setyono DED \& Susetiono. 1990. Pengaruh jenis makanan terhadap pertumbuhan anakan beronang (Siganus canaliculatus). Perairan Maluku dan Sekitarnya, 4:64-70.

Simanjuntak CPH, Zahid A. 2009. Kebiasaan makanan dan perubahan ontogenik makanan ikan baji-baji (Grammoplites scaber) di Pantai Mayangan, Jawa Barat. Jurnal Iktiologi Indonesia, 9(1): 63-73.

Soemodihardjo S. 1977. Beberapa Segi Biologi Hutan Payau dan Tinjauan Singkat Komunitas Mangrove di Gugusan Pulau Pari. Oseana 3(4-5): 24-32.

Suryawan, F. 2007. Studi Kondisi Vegetasi Dan Kondisi Fisik Kawasan Pesisir Serta Upaya Konservasi Di Nanggroe Aceh Darussalam. Sekolah Pascasarjana Institut Pertanian Bogor. Bogor.

Tampubolon, P.A.R.P., Y. Ernawati dan M.F. Rahardjo.2018. Keragaman Iktiofauna Muara Sungai Cimanuk, Indramayu, Jawa Barat. Berita Biologi 17(1): 39-48

Widiadmoko, W. 2013. Pemantauan Kualitas Air Secara Fisika dan Kimia di Perairan Teluk Hurun. Bandar Lampung: Balai Besar Pengembangan Budidaya Laut (BBPBL) Lampung. 